\title{
Mechanical properties of anorthite based ceramics prepared from kaolin DD2 and calcite
}

\author{
(Propriedades mecânicas de cerâmicas à base de anortita \\ preparadas da reação de caulim DD2 e calcita)
}

\author{
A. Harabi, S. Zaiou, A. Guechi, L. Foughali, E. Harabi, N.-E. Karboua, S. Zouai, F.-Z. Mezahi, F. Guerfa \\ Ceramics Lab., Faculty of Exact Science, Physics Department, Mentouri University of Constantine, \\ Constantine 25000, Algeria \\ harabi52@gmail.com,Zaiou_21@yahoo.fr,guechia@yahoo.fr, semouni84@gmail.com, kanour17@yahoo.fr, \\ foughali_lazhar@yahoo.fr,zouaisouheila@yahoo.fr,mezahif@yahoo.fr,guerfatiha@gmail.com
}

\begin{abstract}
Good quality ceramics costs a lot that has limited their use in developing countries. This work was devoted to prepare low-cost and good quality anorthite based ceramics. The proposed composition was $80 \mathrm{wt} \%$ kaolin (DD2 type) and $20 \mathrm{wt} \%$ calcium oxide $(\mathrm{CaO})$. The choice of these raw materials was dictated by their natural abundance coupled with a modified milling system, as another interesting advantage. Previous studies have shown that a simple vibratory multidirectional milling system using bimodal distribution of highly resistant ceramic milling elements has been successfully applied for obtaining fine powders. The influence of the relatively lower sintering temperature, ranging from 800 to $1100{ }^{\circ} \mathrm{C}$, on the porosity and the average pore size (APS) have been investigated. The APS and the porosity values of samples sintered at $950{ }^{\circ} \mathrm{C}$ were about $1 \mu \mathrm{m}$ and $4 \%$, respectively. The best Vickers microhardness and 3-point bending strength values for these sintered samples, using this proposed milling system, were 7.1 $\mathrm{GPa}$ and $203 \mathrm{MPa}$, respectively. Finally, the crystalline phase evolution during heat treatment was investigated by X-ray diffraction, Fourier transform infrared spectroscopy and scanning electron microscopy techniques.
\end{abstract}

Keywords: anorthite, kaolin, calcite, sintering.

\section{Resumo}

Cerâmicas de boa qualidade têm alto custo, o que limita o seu uso em países em desenvolvimento. Este trabalho foi dedicado a preparar cerâmicas à base de anortita de boa qualidade e baixo custo. A composição proposta foi de $80 \%$ em massa de caulim (tipo DD2) e $20 \%$ em massa de óxido de cálcio (CaO). A escolha destas matérias-primas foi determinada pela sua abundância natural e associada a um sistema de moagem modificado, considerado aqui como outra vantagem. Estudos anteriores mostraram que um sistema de moagem multidireccional vibratório, que utiliza distribuição bimodal de elementos de moagem de cerâmica resistentes, foi aplicado com sucesso para a obtenção de pós finos. Foi investigada a influência da temperatura de sinterização no intervalo de 800 a $1100{ }^{\circ} \mathrm{C}$ na porosidade e no tamanho médio dos poros (APS). Os valores de APS e porosidade das amostras sinterizadas a $950{ }^{\circ} \mathrm{C}$ obtidos foram 1 um e 4\%, respectivamente. Os melhores valores de microdureza Vickers e resistência à flexão em 3 pontos para as amostras sinterizadas foram de 7,1 GPa e 203 MPa, respectivamente. Finalmente, a evolução da fase cristalina durante o tratamento térmico foi investigada por técnicas de difração de raios $X$, espectroscopia de infravermelho com transformada de Fourier e microscopia eletrônica de varredura.

Palavras-chave: anortita, caulim, calcita, sinterização.

\section{INTRODUCTION}

Anorthite is widely spread in nature and belongs to the plagioclase group of rock forming minerals. Plagioclases represent a continuous series of solid solutions between anorthite $\left(\mathrm{CaO} \cdot \mathrm{Al}_{2} \mathrm{O}_{3} .2 \mathrm{SiO}_{2}\right)$ and albite $\left(\mathrm{Na}_{2} \mathrm{O} \cdot \mathrm{Al}_{2} \mathrm{O}_{3} \cdot 6 \mathrm{SiO}_{2}\right)$ and form an enormous group of triclinic minerals. The anorthite structure belongs to the framework group and consists of $\left[\mathrm{SiO}_{4}\right]^{4-}$ and $\left[\mathrm{AlO}_{4}\right]^{5-}$ tetrahedral linked by $\mathrm{Ca}^{2+}$. Its theoretical density varies from 2.74 to $2.76 \mathrm{~g} / \mathrm{cm}^{3}$.
Mineralogically, anorthite is reported as a chemically weak mineral, resulting in a basic reaction when dissolved into boiling water, while strong acidic and basic solutions dissolve it. Glass-ceramics and ceramics with crystalline anorthite are mainly used in electrical, thermo-mechanical and water resistance applications [1-4].

Anorthite is an important technical ceramic material that has good physical properties, such as very low thermal expansion coefficient, low dielectric constant and loss, good thermal shock resistance, and high creep resistance at high 
temperatures. For these reasons, several studies were carried out to improve these properties in the past few years [5-8]. In order to prepare low-cost ceramics, many researchers have used low-cost starting materials such as clay, dolomite $\left(\mathrm{CaCO}_{3} \cdot \mathrm{MgCO}_{3}\right)$, bones [natural derived hydroxyapatite, HA: $\left.\mathrm{Ca}_{10}\left(\mathrm{PO}_{4}\right)_{6}(\mathrm{OH})_{2}\right]$, feldspar, quartz, calcite $\left(\mathrm{CaCO}_{3}\right)$ and kaolin. In this work, the long-term goal is the development of a low cost anorthite from inexpensive raw materials, such as kaolin and calcite $\left(\mathrm{CaCO}_{3}\right)$ using a modified milling system. Many works have already been published for appreciating these native raw materials including bioceramics [9-17], advanced ceramics [18-27] and ceramic membranes [2842]. Most of these publications are closely related to this work and clearly highlight their possible applications. As far as ceramic membranes publications are concerned [2842], a lot of low cost materials were also fabricated using the abundantly available raw materials as mentioned above. More recently, porous tubular ceramic composite microfiltration membranes were prepared by an extrusion method using kaolin and calcium carbonates as starting materials, carried out in [42]. The porous gehlenite $\left(2 \mathrm{CaO} \cdot \mathrm{Al}_{2} \mathrm{O}_{3} \cdot \mathrm{SiO}_{2}\right)$ and anorthite based ceramics were obtained by a solid-state reaction. A ceramic support, sintered at $1250{ }^{\circ} \mathrm{C}$, with an average pore size of about $8 \mu \mathrm{m}$, a porosity of about $47 \%$ and compression strength around $40 \mathrm{MPa}$ was prepared; a microfiltration active top layer was deposited on the support by a slip casting from clay powder suspensions. The new elaborated microfiltration membrane layer has a thickness of about $40 \mu \mathrm{m}$ and an average pore size (APS) value of about $0.2 \mu \mathrm{m}$. The performance of the new microfiltration ceramic membrane was determined by evaluating both the water permeability and rejection [42]. This proved the potentiality of the membrane produced in the microfiltration field. Moreover, the good adhesion, between the support and the active microfiltration layer membranes was also proved.

Anorthite based ceramics can be obtained by a controlled devitrification of glass, sometimes with addition of a nucleation agent [2, 43], or from kaolin and calcium carbonate mixtures. Anorthite was prepared from raw materials (kaolin and limestone) for the first time in [2]. Therefore, the use of kaolin as a major starting material provides an economical option. Bouzerara et al. [29] studied the mechanical properties of ceramics, which was prepared from raw materials. For example, the best 3-point flexural strength (3PFS) was about $41 \mathrm{MPa}$ for samples sintered at $1250{ }^{\circ} \mathrm{C}$ for $1 \mathrm{~h}$, when $15 \mathrm{wt} \%$ doloma $(\mathrm{CaO} . \mathrm{MgO})$ powder was added into kaolin. Also, a 3PFS value of about $87 \mathrm{MPa}$ was obtained in [35], using kaolin $+15 \mathrm{wt} \%$ calcite (K15C) selected mixture, sintered at $1250^{\circ} \mathrm{C}$ for $1 \mathrm{~h}$. In this way, the anorthite $\left(\mathrm{CaO} \cdot \mathrm{Al}_{2} \mathrm{O}_{3} .2 \mathrm{SiO}_{2}\right)$ based ceramics were prepared from kaolin halloysite type $\left(\mathrm{Al}_{2} \mathrm{O}_{3} \cdot 2 \mathrm{SiO}_{2} \cdot 4 \mathrm{H}_{2} \mathrm{O}\right)$ and $\mathrm{CaCO}_{3}$ using a modified milling system. In fact, the porosity and the APS of samples sintered at different temperatures ranging between 800 and $1100{ }^{\circ} \mathrm{C}$ were investigated. This study is also focused on the effect of firing temperatures $\left(800\right.$ to $\left.1100{ }^{\circ} \mathrm{C}\right)$ on mechanical properties of anorthite based ceramics.

\section{EXPERIMENTAL}

The anorthite were prepared from domestic kaolin (DD2, $\mathrm{Al}_{2} \mathrm{O}_{3} \cdot 2 \mathrm{SiO}_{2} \cdot 4 \mathrm{H}_{2} \mathrm{O}$ ) and calcium oxide extracted from calcium carbonate $\left(\mathrm{CaCO}_{3}\right)$ obtained from Guelma and Constantine regions in Algeria, respectively. The chemical composition of kaolin (DD2) is given in [5]. The obtained results revealed that this kaolin is mainly composed of silica $\left(45.0 \% \mathrm{SiO}_{2}\right)$ and alumina $\left(33.43 \% \mathrm{Al}_{2} \mathrm{O}_{3}\right)$, where the main impurities are $\mathrm{Na}_{2} \mathrm{O}(1.12 \%), \mathrm{K}_{2} \mathrm{O}(0.95 \%), \mathrm{CaO}(0.32 \%)$, $\mathrm{TiO}_{2}(0.22 \%)$ and $\mathrm{Fe}_{2} \mathrm{O}_{3}(0.23 \%)$ [5, 44]. The particle size distribution of this material was determined by the dynamic laser beam scattering (DLBS) technique; this method gave an average particle size of $2.2 \mu \mathrm{m}$ [45]. The kaolin powder was obtained by calcination of the final ground mineral at $520{ }^{\circ} \mathrm{C}$ for $1 \mathrm{~h}$. The $\mathrm{CaCO}_{3}$ powder was calcined at $900{ }^{\circ} \mathrm{C}$ for $12 \mathrm{~h}$ then hydrated in bi-distilled water and followed by a second calcination at $800{ }^{\circ} \mathrm{C}$ for $2 \mathrm{~h}$. The quantitative analysis of these calcium carbonates showed that the purity of this raw material is about $99.7 \%$, using X-ray fluorescence (XRF) analysis. As reported in [46], this raw material may be classified as a high-purity calcium oxide $(\mathrm{CaO} \geq 99.0 \%)$. The particle size distribution of calcite was determined by DLBS, which gave an average particle size of $4.8 \mu \mathrm{m}$ [45].

Because the starting kaolin and calcite powders undergo structural evolution and weight loss during their heating, thermogravimetric analysis (TGA) and differential scanning calorimetry (DSC) have been judged useful before any other characterization techniques. These two analyses were carried out under air using a Setaram TG-DTA 92 apparatus. The heating rate of the compacts from room temperature to $1200{ }^{\circ} \mathrm{C}$ was $10^{\circ} \mathrm{C} / \mathrm{min}$, whilst the cooling of compacts was carried out in the furnace. TGA curve recorded during compact heating (Fig. 1) permit to remark that a total weight loss rate (WLR) of about $18 \%$ for kaolin. In fact, this WLR consists of two distinct stages. The first one is attributed to the humidity (water added into the starting mixtures) whereas the second is related to the kaolin chemical composition water loss (by vaporization) itself. These observations are

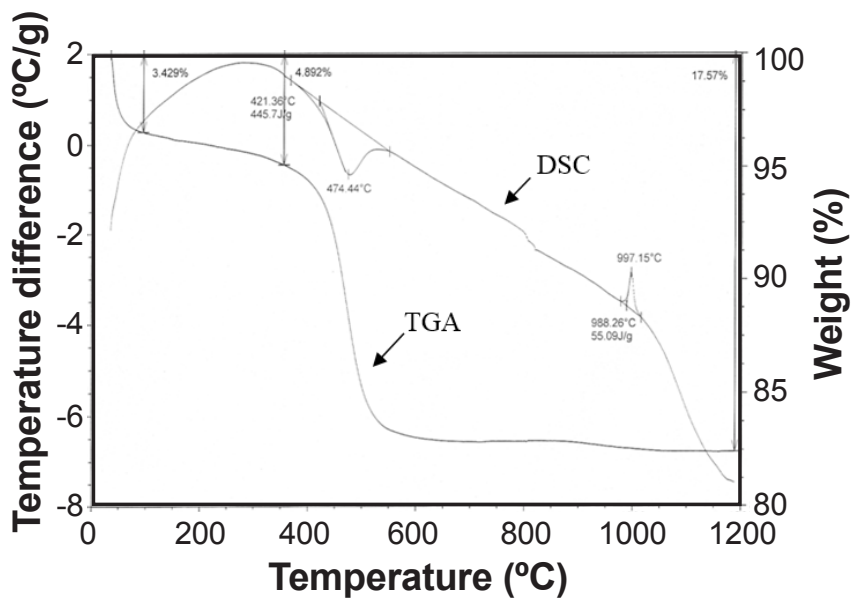

Figure 1: DSC and TGA curves for kaolin (DD2) powder. [Figura 1: Curvas das análises de DSC e TG do caulim (DD2).] 
also confirmed by DSC analysis (Fig. 1). This later exhibits characteristic endothermic peaks, appearing at 95 and $474{ }^{\circ} \mathrm{C}$ and exothermic peaks at $997{ }^{\circ} \mathrm{C}$ where this reaction may be attributed to mullite nucleation [47]. For the calcium carbonate, TGA and DSC analysis showed that there is only endothermic peak (mass loss of $43.73 \%$ ) in the range of 650 to $800{ }^{\circ} \mathrm{C}$, which may be due to the thermal decomposition of $\mathrm{CaCO}_{3}$ into calcium oxide $(\mathrm{CaO})$ and $\mathrm{CO}_{2}$ [48].

For preparation of anorthite, an amount of about $20 \mathrm{wt} \%$ of $\mathrm{CaO}$ extracted from local $\mathrm{CaCO}_{3}$ was added to the kaolin (DD2); the powders were milled using a particular homemade vibratory milling system for $17 \mathrm{~h}$. Then, they were dried and calcined at $800{ }^{\circ} \mathrm{C}$ for $2 \mathrm{~h}$. The test specimens for firing tests, shaped as discs of about $13 \mathrm{~mm}$ diameter and $2 \mathrm{~mm}$ thickness, were obtained after uniaxial pressing of powders at $75 \mathrm{MPa}$. The dried samples were sintered at various temperatures ranging between 800 and $1100{ }^{\circ} \mathrm{C}$ following the firing cycle given in Fig. 2. Further details about the samples preparation, including the flowchart of main route used in this work for anorthite samples elaboration, can be found elsewhere [5].

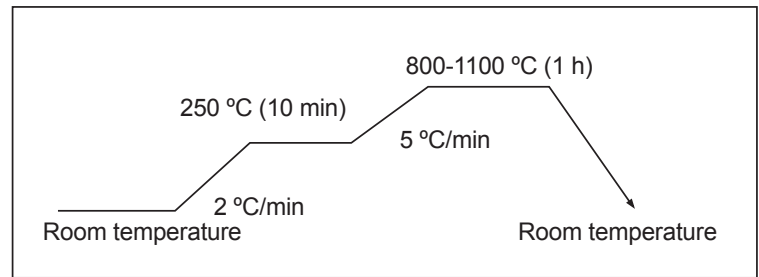

Figure 2: Scheme of the thermal treatment for anorthite samples.

[Figura 2: Esquema do tratamento térmico para a preparação das amostras de anortita.]

The phase compositions of the prepared samples were identified by X-ray diffraction (XRD, Bruker, D8 Advance) with a $\mathrm{CuK} \alpha$ radiation $(\lambda=0.154 \mathrm{~nm}$ ) and a Ni filter, working voltage of $40 \mathrm{kV}$ and working current of $30 \mathrm{~mA}$. Fourier transform infrared spectroscopy (FTIR, Bruker Equinox $55 ; 4000-400 \mathrm{~cm}^{-1}$ ) was also used. The microstructure of sample surfaces was observed by a scanning electron microscope (SEM, Hitachi, JSM-6301 F) working at $7 \mathrm{kV}$ as an accelerating voltage. Before SEM observation, all samples were gold coated. The total porosity and pore size distribution were measured by mercury porosimetry (Micromeritics, Autopore 9500). This technique is based on the penetration of mercury into a sample's pore under pressure. The intrusion volume was recorded as a function of the applied pressure and then the pore size is determined.

The tensile strength testing of specimens was obtained using a diametral compression test (Form Test Seidner D 79-40). One of the fundamental aspects of this test is the relatively small proportion of the specimen volume which reaches the peak stress at fracture. In its simplest form, a right circular cylindrical specimen compressed diametrally between two flat platens. A biaxial stress state is produced within the test specimen and, on the assumption of ideal line loading; the vertical plane is subjected to a uniform horizontal tensile strength of magnitude:

$$
\sigma_{\mathrm{t}}=2 \mathrm{P} /(\pi \mathrm{dt})
$$

where $\sigma_{t}(\mathrm{MPa})$ is the maximum tensile stress, $\mathrm{P}(\mathrm{N})$ is the applied load at fracture, $\mathrm{d}(\mathrm{mm})$ is the specimen diameter and $\mathrm{t}(\mathrm{mm})$ is the specimen thickness. The correspondence between measured tensile strength $\left(\sigma_{t}\right)$ value and its equivalent 3-point flexural (bending) strength $\left(\sigma_{\mathrm{f}}\right)$ is given by the following equation:

$$
\sigma_{\mathrm{f}}=2.7 \sigma_{\mathrm{t}}
$$

This equation was also confirmed by [49]. It should be noticed that this deduced flexural strength is needed for comparison since it is generally used by the major investigators, and that hundreds of samples within the 2 different shapes have been tested separately. So, it has also been confirmed that the conversion ratio between flexural strength and tensile strength of samples is always interchangeable. Vickers microhardness values were measured with microhardness testing machine (Leitz Wetzlar 6844). All the values presented are the average of at least three specimens.

\section{RESULTS AND DISCUSSION}

Phase identification is of great importance after anorthite fabrication, because the presence of certain phases may limit its application (e.g., ceramic membranes). XRD was used to identify the formed phases in samples, sintered at $950{ }^{\circ} \mathrm{C}$. The main phase detected in samples fired at different temperatures was only anorthite $\left(\mathrm{CaO} . \mathrm{Al}_{2} \mathrm{O}_{3} \cdot 2 \mathrm{SiO}_{2}\right.$, JCPDS 20-0020), as illustrated in Fig. 3 , since sintering produces a series of reactions or phase transformations that may lead to the anorthite formation [5]. Furthermore, the decomposition reaction of $\mathrm{CaCO}_{3}$ into $\mathrm{CaO}$ and $\mathrm{CO}_{2}$ is also confirmed by XRD analysis $[5,50]$. One of the main objectives in this subsection is

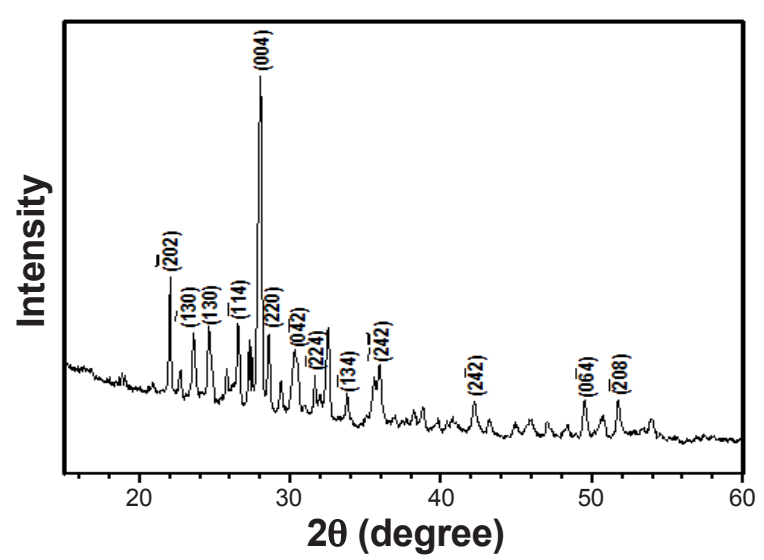

Figure 3: X-ray diffraction pattern of anorthite sample sintered at $950{ }^{\circ} \mathrm{C}$ for $1 \mathrm{~h}$.

[Figura 3: Difratograma de raios $\mathrm{X}$ da amostra sinterizada a $950^{\circ} \mathrm{C}$ por $\left.1 \mathrm{~h}.\right]$ 
to find out the appropriate amount of $\mathrm{CaO}$ composing the final mixture to obtain an anorthite phase alone. This is why $\mathrm{CaO}$ is added at a particular proportion $(20 \mathrm{wt} \%)$ into kaolin and the mixture is sintered at $950{ }^{\circ} \mathrm{C}$. It should also be noticed that $\mathrm{CaO}$ used in this work instead of $\mathrm{CaCO}_{3}$ was activated according to [20].

Since XRD, did not detect amorphous phases, using FTIR is well recommended in order to identify if there is any non-crystallized phase in the sintered samples. The FTIR spectrum of the sample confirmed the anorthite stability at $950^{\circ} \mathrm{C}$ (Fig. 4). The results illustrate the anorthite characteristic bands: $\mathrm{Si}-\mathrm{O}-\mathrm{Al}$ (at around 535 and $758 \mathrm{~cm}^{-1}$ ), $\mathrm{Si}-\mathrm{O}$ (at around $697 \mathrm{~cm}^{-1}$ ), Si-O-Si (at around $1011 \mathrm{~cm}^{-1}$ ) and $\mathrm{Al}-\mathrm{OH}$ (at around $914 \mathrm{~cm}^{-1}$ ) [51-54]. The identified phase is of great importance because of its promising physical and mechanical properties. For example, anorthite is a useful refractory for high-temperature ceramics applications because of its low thermal expansion and high creep resistance.

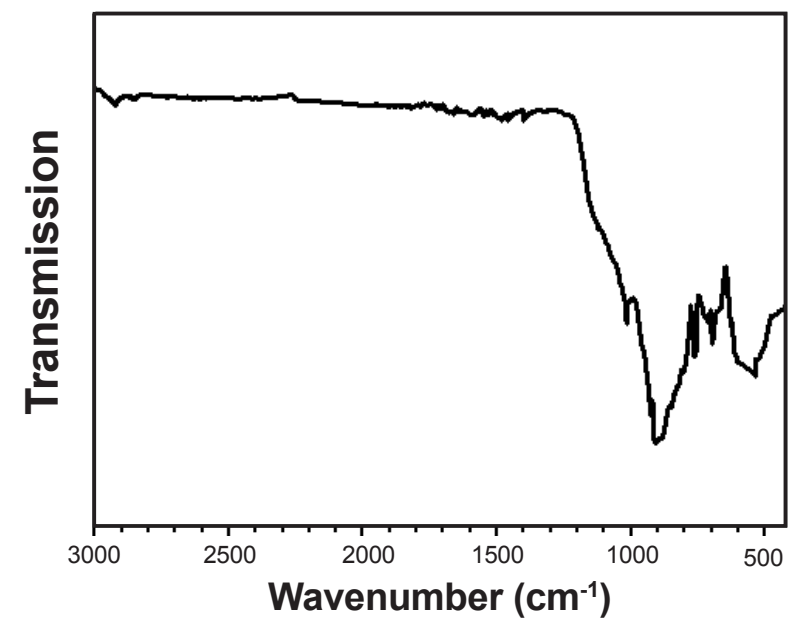

Figure 4: FTIR spectrum of anorthite sample sintered at $950{ }^{\circ} \mathrm{C}$ for $1 \mathrm{~h}$.

[Figura 4: Espectro de FTIR da amostra sinterizada a $950{ }^{\circ} \mathrm{C}$ por 1 h.]

For the development of high-quality anorthite product, the following properties are of major importance: porosity, average pore size (APS) and mechanical properties. According to the previous results, there is a relationship between porosity ratio, pore size, sintering temperature and mechanical properties $[35,55,56]$. As shown in Fig. 5 , porosity and APS behavior were function of sintering temperature. The porosity and APS values decreased considerably in the temperature range between 800 and $1000{ }^{\circ} \mathrm{C}$. For example, the porosity ratio decreased from $42 \%$ to about $4 \%$ when sintering temperature increased from 800 to $950{ }^{\circ} \mathrm{C}$, whereas APS decreased from 6 to $1 \mu \mathrm{m}$ at the same sintering temperature interval. This decrease in porosity and APS values may be due to a better sintering; this result highlights the importance of using the modified milling system and native natural materials (kaolin DD2 type and $\mathrm{CaCO}_{3}$ ). When this process was applied, the powder particles were drastically smaller. Moreover, the morphology of particles had elongated and spherical shapes. By contrast, the porosity increased for samples sintered at temperatures higher than $1000{ }^{\circ} \mathrm{C}$. This increase may be attributed to the formation of an excessive liquid phase. In fact, the increase in the sintering temperature encourages excessive formation of the liquid phase which inhibits sintering in its turn. In addition, higher sintering temperatures may lead to some gases involved in the chemical composition of raw materials, which leaved behind it large pores that are difficult to be driven out. So, this may be the main factor controlling this increase in porosity rate. The APS is also confirmed by a typical micrograph illustrated in Fig. 6 . Finally, both porosity and APS values indicate that this kind of anorthite based ceramics may be used in large application domains.

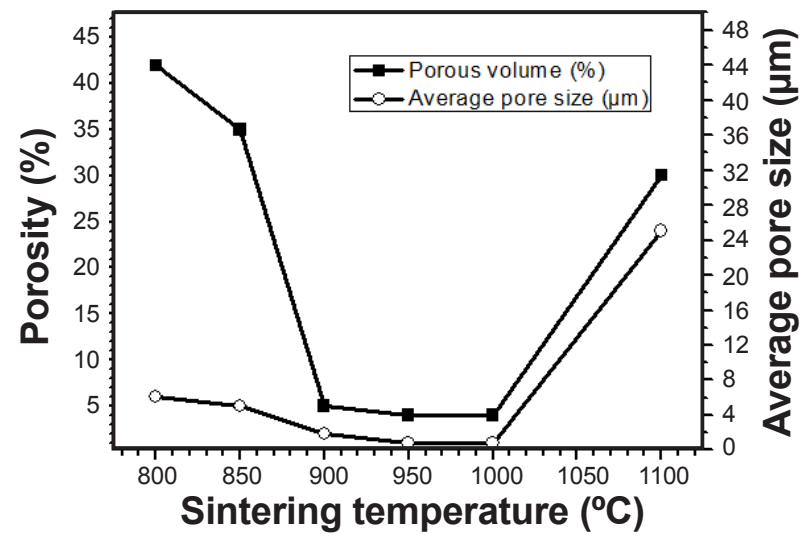

Figure 5: Effect of sintering temperature on porosity and APS of anorthite samples.

[Figura 5: Efeito da temperatura de sinterização na porosidade e no tamanho médio de poros das amostras de anortita.]
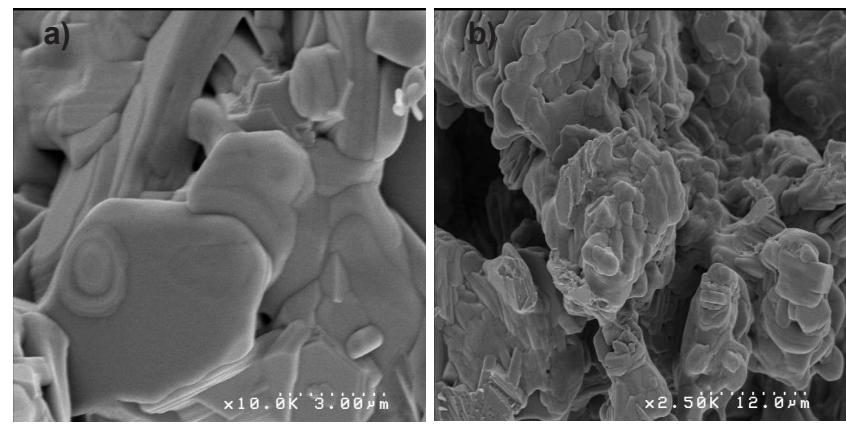

Figure 6: SEM micrographs illustrating submicrometric anorthite grains for the sample sintered at $950{ }^{\circ} \mathrm{C}$ for $1 \mathrm{~h}$.

[Figura 6: Micrografias obtidas por microscopia eletrônica de varredura ilustrando grãos submicrométricos na amostra sinterizada a $950^{\circ} \mathrm{C}$ por $\left.1 \mathrm{~h}.\right]$

After pore characterization and phase identification of prepared samples, mechanical properties measurements are also of great importance.Fig. 7 shows Vickers microhardness values of sintered anorthite samples. As would be expected, there was a significant increase in Vickers microhardness with the increase in sintering temperature (from 800 to $1000{ }^{\circ} \mathrm{C}$ ) of samples. Microhardness value of about 7.1 GPa 


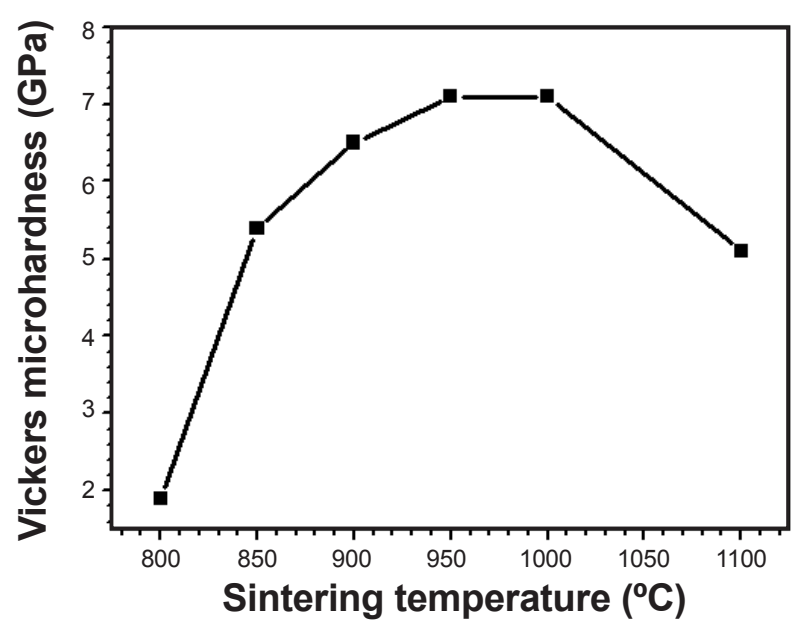

Figure 7: Vickers microhardness of samples sintered at different temperatures for $1 \mathrm{~h}$.

[Figura 7: Microdureza Vickers para as amostras sinterizadas em diferentes temperaturas por $1 \mathrm{~h}$.

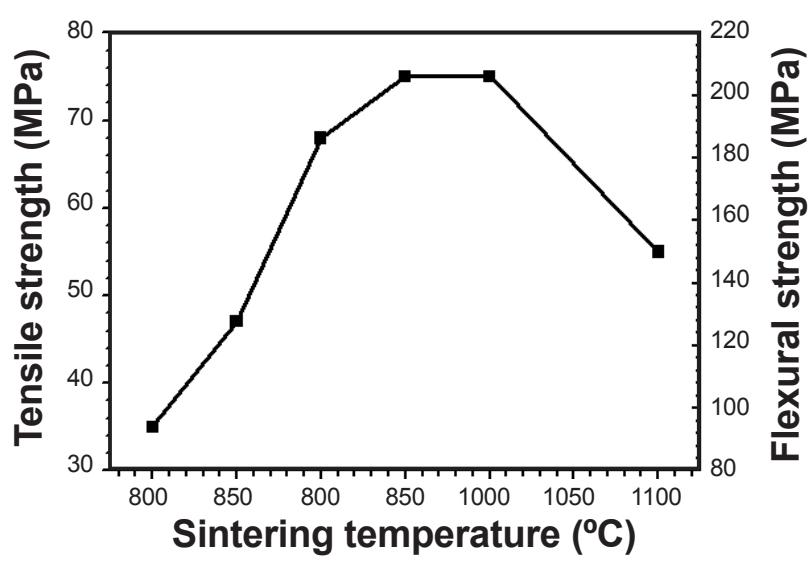

Figure 8: Results of strength of samples sintered at different temperatures for $1 \mathrm{~h}$.

[Figura 8: Resultados de resistência para as amostras sinterizadas a diferentes temperaturas por $1 \mathrm{~h}$.

is obtained for samples sintered at a relatively low temperature (about $950{ }^{\circ} \mathrm{C}$ ). When sintering temperature becomes higher than $1000{ }^{\circ} \mathrm{C}$, a remarkable decrease in the Vickers microhardness for the samples was observed. Indeed, the best hardness value was significantly higher $(7.1 \mathrm{GPa})$ when compared to that of human dental enamel (4 GPa) [14], and therefore is more appropriate for dental restoration purpose. Consequently, this result clearly shows the importance of the obtained value of Vickers microhardness as compared (within the error bars) to one of the most resistant bioceramics (wollastonite based ceramics) [14]. In fact, these interesting Vickers microhardness values are of great importance for many biomaterial applications.

A typical curve of the tensile strength of anorthite samples, prepared according to the proposed process, as a function of sintering temperature is illustrated in Fig. 8. This figure shows that the 3-point flexural strength (3PFS) increased gradually from 81 to about $203 \mathrm{MPa}$ for samples sintered at temperatures ranging from 800 to $1000{ }^{\circ} \mathrm{C}$. It was observed that a flexural strength of about $203 \mathrm{MPa}$ was also obtained for samples sintered at $950{ }^{\circ} \mathrm{C}$. Afterwards, the flexural strength decreased significantly above $1000{ }^{\circ} \mathrm{C}$. Additionally, typical SEM micrograph of the fracture surface of samples sintered at $950{ }^{\circ} \mathrm{C}$ for $1 \mathrm{~h}$ is given in Fig. 6. This figure confirms that the more densified samples correspond to the more resistant ones.

One can compare the obtained flexural strength values using the present work with those reported by other studies carried out on anorthite based ceramics and particular materials [35]. For example, the best 3PFS (203 MPa) in this work was obtained for the anorthite sintered at $950{ }^{\circ} \mathrm{C}$ for $1 \mathrm{~h}$ using the original milling system. It should be noticed that this high strength is in a good agreement with the microstructure shown in Fig. 6. Consequently, this flexural strength value is extremely higher than that reported by other works carried out on similar based ceramics [29, 57-61]. This value (203 MPa) is also significantly higher than those reported in [57] (40 MPa) and [60] (36 MPa) for their prepared membrane supports (application of anorthite), although they have been sintered at relatively higher temperatures $\left(\geq 1450^{\circ} \mathrm{C}\right)$. This result clearly shows the importance of the obtained value of flexural strength. In fact, these interesting flexural strength values are of great importance for many anorthite based ceramics, ceramic membranes and biomaterial applications.

A careful look at the Figs. 5, 7 and 8, concerning sample characterizations, shows that the flexural strength may be controlled by many factors. Hence, a general correlation seems to exist between densification, microstructural changes (average grain size and pore distribution) and tensile strength in sintered compacts. Usually, densification and grain size are the dominant factors controlling strength, since most of the total pores were intergranular. The substantial increase in strengths of samples corresponded to a parallel increase in density which means a decrease in porosity ratio. This is true when a sinterable product such as anorthite is concerned.

\section{CONCLUSIONS}

The present work is an attempt for the fabrication of anorthite $\left(\mathrm{CaO} \cdot \mathrm{Al}_{2} \mathrm{O}_{3} \cdot 2 \mathrm{SiO}_{2}\right)$ based ceramics using economical natural local raw materials. The proposed composition was $80 \mathrm{wt} \%$ kaolin (DD2 type) and $20 \mathrm{wt} \%$ $\mathrm{CaO}$. Using this composition, the samples were sintered at different temperatures ranging between 800 and $1100{ }^{\circ} \mathrm{C}$. Excellent porosity (4\%), Vickers microhardness (7.1 GPa) and flexural strength (203 MPa) values of anorthite samples have been achieved. The importance of using both the modified milling system and native natural materials (kaolin DD2 type and $\mathrm{CaCO}_{3}$ ) were put into evidence. Additionally, the main phase identified in all samples was only anorthite as a stable phase, using XRD, FTIR and SEM. Finally, the relatively promising characteristics mentioned above may extend further the application domains of these elaborated anorthite based ceramics. 


\section{REFERENCES}

[1] E.Y. Medvedovskii, F.Y. Kharitonov, T.D. Shcherbina, Glass. Ceram. 46 (1990) 204.

[2] Y. Kobayashi, E. Kato, J. Am. Ceram Soc. 77 (1994) 833. [3] I. Yasui, B. Ryu, T. Kawarazaki, J. Am. Ceram. Soc. 30 (1993) 323.

[4] D.U. Tulyaganov, A.A. Ismatov, J. Am. Ceram. Soc. 29 (1993) 221.

[5] S. Zaiou, A. Harabi, E. Harabi, A. Guechi, N. Karboua, M.T, Benhassine S. Zouai, F. Guerfa, Cerâmica 62, 364 (2016) 317.

[6] G. Balakrishnan, F.C. Reid, D. Bruhn, L. Kohlstedt, J. Am. Ceram Soc. 84 (2001) 2617.

[7] S. Kavalci, E. Yalamac, S. Akkurt, Ceram. Int. 34 (2008) 1629.

[8] S. Kurama, E. Ozel, Ceram. Int. 35 (2009) 827.

[9] A. Harabi, E. Harabi, S. Chehalatt, S. Zouai, N. Karboua, L. Foughali, Des. Wat. Treat. 57 (2016) 5309.

[10] E. Harabi, A. Harabi, F.Z. Mezahi, S.Zouai, N. Karboua, S. Chehalatt, Des. Wat. Treat. 57 (2016) 5302.

[11] E. Harabi, A. Harabi, L. Foughali, S. Chehlatt, S. Zouai, F.Z. Mezahi, Acta. Phys. Pol. A 127 (2015) 1161.

[12] L. Foughali, A. Harabi, J.P. Bonnet, D. Smith, B. Boudaira, Cerâmica 60, 356 (2014) 546.

[13] A. Binnaz, Y. Hazar, Ceram. Int. 33 (2007) 687.

[14] A. Harabi, S. Chehlatt, J. Therm. Anal. Calorim. 111 (2013) 203.

[15] A. Harabi, S. Zouai, Int. J. Appl. Ceram. Technol. 11 (2014) 31.

[16] S. Chehlatt, A. Harabi, E. Harabi, S. Zouai, H Oudadesse, S.E. Barama, Des. Wat. Treat. 57 (2016) 5296.

[17] S. Chehlatt, A. Harabi, H. Oudadesse, E. Harabi, Acta. Phys. Pol. A 127 (2015) 925.

[18] A. Harabi, E. Harabi, Mater. Sci. Eng. C 51 (2015) 206. [19] S. Zouai, A. Harabi, N. Karboua, E. Harabi, S. Chehlatt, S.E. Barama, S. Zaiou, F. Bouzerara, F. Guerfa, Mater. Sci. Eng. C 61 (2016) 553.

[20] A. Harabi, S. Achour, J. Mater. Sci. Lett. 18 (1999) 955.

[21] M.R. Boudchicha, S. Achour, A. Harabi, J. Mater. Sci. Lett. 20 (2001) 215.

[22] A. Mecif, J. Soro, J.P. Bonnet, A. Harabi, J. Am. Ceram. Soc. 93 (2010) 1306.

[23] A. Harabi, N. Karboua, S. Achour, Int. J. Appl. Ceram. Technol. 9 (2012) 124.

[24] A. Harabi, T.J. Davies, Br. Ceram. Trans. J. 94 (1995) 79.

[25] A. Harabi, T.J. Davies, Br. Ceram. Trans. J. 94 (1995) 97.

[26] S. Kitouni, A. Harabi, Cerâmica 57, 344 (2011) 453.

[27] O. Toumiat, S. Achour, A. Harabi, N. Tabet, M. Boumaour, M. Maallemi, Nanotech. 17 (2006) 658.

[28] O. Bourbia, S. Achour, N. Tabet, M. Parlinska, A. Harabi, Thin Solid Films 515 (2007) 6758.

[29] F. Bouzerara, A. Harabi, S. Achour, A. Labrot, J. Eur. Ceram. Soc. 26 (2006) 1663.

[30] A. Harabi, F. Bouzerara, S. Condom, Des. Wat. Treat.
6 (2009) 222.

[31] B. Boudaira, A. Harabi, F. Bouzerara, S. Condom, Des. Wat. Treat. 9 (2009) 142.

[32] F. Bouzerara, A. Harabi, S. Condom, Des. Wat. Treat. 12 (2009) 415.

[33] A. Harabi, A. Guechi, S. Condom, Procedia Eng. 33 (2012) 220.

[34] C.N. Djanganga, E. Kamseu, M. Kor Ndikontar, G.L. Nana, J. Soro, U.C. Melo, A. Elimbi, P. Blanchart, D. Njopwouo, Mater. Sci. Eng. A 528 (2011) 8318.

[35] A. Harabi, F. Zenikheri, B. Boudaira, F. Bouzerara, A. Guechi, L. Foughali, J. Eur. Ceram. Soc. 34 (2014) 1329.

[36] L. Foughali, A. Harabi, S.E. Barama, F. Bouzerara, A. Guechi, B. Boudaira, Des. Wat. Treat. 57 (2016) 5291.

[37] K. Ezziane, A. Belouatek, E. Selmane, B. Hmida, Desalination 250 (2010) 422.

[38] A. Harabi, B. Boudaira, F. Bouzerara, L. Foughali, F. Zenikheri, A. Guechi, B. Ghouil, S. Condom, Acta. Phys. Pol. A 127 (2015) 1164.

[39] L.F. Han, Z.L. Xu, Y. Cao, Y.M. Wei, H.T. Xu, J. Membr. Sci. 372 (2011) 164.

[40] J. Bai, Ceram. Int. 36 (2010) 678.

[41] T. Mohammadi, A. Pak. J. Sep. Purf. Sci. 30 (2003) 241.

[42] B. Ghouil, A. Harabi, F. Bouzerara, B. Boudaira, A. Guechi, M.M. Demir, A. Figoli, Mater. Charact. 103 (2015) 18.

[43] H.C. Park, S.H. Lee, B.K. Ryu, M.M. Son, H.S. Lee, I. Yasui, J. Mater. Sci. 31 (1996) 4249.

[44] S. Masmoudi, A. Larbot, H. El Feki, R. Ben Amar, Desalination 190 (2006) 89.

[45] F. Zenikheri, A. Harabi, B. Boudaira, F. Bouzerara, A. Guechi, S.E. Barama, L. Foughali, N. Karboua, Cerâmica 62, 363 (2016) 242.

[46] W. Ming, Z. Ruzhong, M. Weiqing, L. Yi, J. Mater. Sci.: Mater. Electron. 22 (2011) 843.

[47] K.A. DeFriend, M.R. Wiesner, A.R. Barron, J. Membr. Sci. 224 (2003) 11.

[48] B. Boudaira, A. Harabi, F. Bouzerara, S. Condom, F. Zenikheri, A. Guechi, L. Foughali, N. Karboua, Cerâmica 62, 362 (2016) 186.

[49] A. Harabi, "Studies of an alumina-chromia system containing mullite", PhD Thesis, UMIST, Manchester (1990).

[50] W. Reimann, Desalination 109 (1997) 51.

[51] R.L. Frost, Clay. Miner. 32 (1997) 77.

[52] G. Viruthagiri, K. Ponnarasi, Exp. Sci. 2 (2011) 7.

[53] A. Majouli, S. Alami Younssi, S. Tahiri, A. Albizane, H. Loukili, M. Belhaj, Desalination 66 (2011) 277.

[54] R.D. Sahnoun, J. Bouaziz, Ceram. Int. 38 (2012) 7.

[55] S. Khemakhem, R. Ben Amar, R. Ben Hassen, A. Larbot, M. Medhioub, A. Ben Salah, L. Cot, Desalination 167 (2004) 22.

[56] Y. Dong, B. Lin, J. Zhou, X. Zhang, Y. Ling, X. Liu, G. Meng, S. Hampshire, Mater. Charact. 62 (2011) 418.

[57] S. Sarkar, S. Bandyopadhyay, A. Larbot, S. Cerneaux, J. Membr. Sci. 130 (2012) 392. 
[58] G. Chen, H. Qi, W. Xing, N. Xu, J. Membr. Sci. 38 (2008) 318.

[59] S. Kroll, L. Treccani, K. Rezwan, G. Grathwohl, J. Membr. Sci. 55 (2010) 365.

[60] Y. Dong, S. Hampshire, J. Zhou, B. Lin, Z. Ji, X. Zhang,
J. Hazard. Mater. 173 (2010) 180.

[61] A. Harabi, F. Guerfa, E. Harabi, M.T, Benhassine, L. Foughali, S. Zaiou, Mater. Sci. Eng. C 65 (2016) 33.

(Rec. 29/11/2015, Rev. 28/04/2016, 16/08/2016, 15/11/2016, Ac. 20/11/2016) 